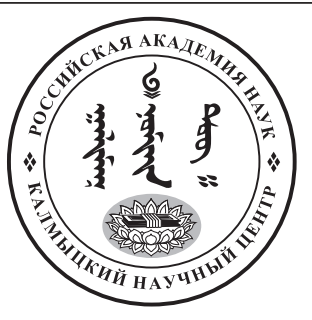

Published in the Russian Federation

Oriental Studies (Previous Name: Bulletin of the Kalmyk Institute

for Humanities of the Russian Academy of Sciences)

Has been issued as a journal since 2008

ISSN: 2619-0990; E-ISSN: 2619-1008

Vol. 13, Is. 3, pp. 493-505, 2020

DOI: $10.22162 / 2619-0990-2020-49-3-493-505$

Journal homepage: https://kigiran.elpub.ru

УДК 94 (510)

DOI: $10.22162 / 2619-0990-2020-49-3-493-505$

\title{
От политики «четырех чисток» к созданию ревкомов в Хулун- Буире (к реконструкции событий начального этапа «культурной революции»)
}

\author{
Базар Догсонович Цыбенов ${ }^{1}$ ЦЦыден Солбонович Очиров²
}

${ }^{1}$ Институт монголоведения, буддологии и тибетологии Сибирского отделения РАН (д. 6, ул. Сахьяновой, 670047 Улан-Удэ, Российская Федерация) кандидат исторических наук, старший научный сотрудник iD 0000-0002-0404-7207.E-mail: bazar75@mail.ru

${ }^{2}$ Институт монголоведения, буддологии и тибетологии Сибирского отделения РАН (д. 6, ул. Сахьяновой, 670047 Улан-Удэ, Российская Федерация) аспирант iD 0000-0002-6705-2820. E-mail: tsyden.ochirov@mail.ru

\author{
(C) КалмНЦ РАН, 2020 \\ (C) Цыбенов Б. Д., Очиров Ц. С., 2020
}

\begin{abstract}
Аннотация. Введение. Актуальной проблемой современного востоковедения является изучение особенностей проведения «культурной революции» на национальных окраинах КНР. Одним из важных в геополитическом отношении приграничных регионов, где проведение идеолого-политической кампании явилось насущной необходимостью ее сторонников, был Хулун-Буирский аймак Автономного района Внутренняя Монголия (АРВМ). Целью исследования является реконструкция политических событий в Хулун-Буирском аймаке в 1965-1968 гг. Задачи исследования расположены в хронологической последовательности: 1) рассмотрение кампании «четырех чисток» и борьбы с «четырьмя пережитками» как предыстории «культурной революции»; 2) освещение кардинальных перемен, произошедших в местных органах власти и в руководстве аймачного парткома в 1966-1968 гг.; 3) изучение репрессивной деятельности хунвейбинов и цзаофаней в Хулун-Буире, их деление на два борющихся лагеря; 4) изучение создания аймачного ревкома и его деятельности в 1968 г. Материаль исследования представляют собой три сборника официальных документов по исследуемой проблематике, опубликованные в КНР. Они дополнены рядом работ отечественных и зарубежных авторов, в ряде случаев проводится сравнительно-сопоставительный анализ событий и фактов. Резульmambl: прослежен органичный переход от идейно-политических кампаний начала 1960-х гг.
\end{abstract}


к «культурной революции»; установлены события и факты, имевшие место в Хулун-Буирском аймаке в 1966-1968 гг., включая имена репрессированных партийных руководителей Хулун-Буирского аймака и новых назначенцев из провинций Хубэй и Шаньси, руководства военного совета; на основе данных по эвенкийскому хошуну и хошунов Новой Барги установлено разделение массовых революционных организаций на противоборствующие направления; отмечено усиление репрессий в отношении членов фракций Народно-революционной партии Внутренней Монголии (НРПВМ) в аймаке после создания ревкома Хулун-Буирского аймака и вступления на должность председателя ревкома Шанминя, сторонника радикальных мер в отношении «классовых врагов». Bblводы. Политические события в Хулун-Буирском аймаке в 1965-1968 гг. имели прямую связь как с ситуацией в АРВМ, так и во всем Китае. Назначение кадровых партийных работников из центральных провинций КНР, очевидно, наблюдалось и в других аймаках АРВМ. Особенностью репрессивной политики в Хулун-Буирском аймаке явились гонения на членов фракции «объединения» НРПВМ.

Ключевые слова: «культурная революция», Внутренняя Монголия, Хулун-Буирский аймак, партком, хунвейбины, репрессии, революционный комитет

Благодарность. Исследование проведено в рамках проекта РФФИ № 19-39-90003 «Этнические меньшинства Хулун-Буира в годы культурной революции: политический нарратив и устные истории» (номер госрегистрации: АААА-А20-120052290030-0).

Для цитирования: Цыбенов Б. Д., Очиров Ц. С. От политики «четырех чисток» к созданию ревкомов в Хулун-Буире (к реконструкции событий начального этапа «культурной революции») // Oriental Studies. 2020. Т. 13. № 3. С. 493-505. DOI: 10.22162/2619-0990-2020-49-3-493505

UDC 94 (510)

DOI: $10.22162 / 2619-0990-2020-49-3-493-505$

\title{
From the Policy of 'Four Purges' to the Creation of Revolutionary Committees in Hulunbuir: Reconstructing the Beginnings of China's Cultural Revolution
}

\author{
Bazar D. Tsybenov ${ }^{1}$, Tsyden S. Ochirov ${ }^{2}$
}

${ }^{1}$ Institute for Mongolian, Buddhist and Tibetan Studies, Siberian Branch of the RAS (6, Sakhyanova St., Ulan-Ude 670047, Russian Federation)

Cand. Sc. (History), Senior Research Associate

iD 0000-0002-0404-7207.. E-mail: bazar75@mail.ru

${ }^{2}$ Institute for Mongolian, Buddhist and Tibetan Studies, Siberian Branch of the RAS (6, Sakhyanova St., Ulan-Ude 670047, Russian Federation)

Postgraduate Student

iD 0000-0002-6705-2820. E-mail: tsyden.ochirov@mail.ru

(C) KalmSC RAS, 2020

(C) Tsybenov B. D., Ochirov Ts. S., 2020

Abstract. Introduction. Peculiarities of the 'Cultural Revolution' in China's national regions remain
a poorly studied issue in modern Oriental studies. In this regard, Hulunbuir league of the Inner
Mongolia Autonomous Region had been a strategically important and geopolitically significant region
of the country. This territory bordered on the Mongolian People's Republic and the USSR, therefore
the central government of China considered its population potentially dangerous and marginal. The
People's Revolutionary Party of Inner Mongolia had two party factions in Hulunbuir league: the
'unification' faction, and the 'justice' one. The Maoists viewed the 'Mongol Unification' faction of 
the People's Revolutionary Party of Inner Mongolia as a particularly dangerous, separatist trend. Goals. The paper aims to examine the political events and facts that took place in Hulunbuir league in 1965-1968. Objectives. Chronologically, the first objective is to examine the ideological and political campaigns — struggle against the 'Four Olds', and the 'Four Purges' — as a prehistory to the 'Cultural Revolution'. The second objective is to analyze the cardinal changes that took place in the leadership of the party committee and local authorities in 1966-1968. The third problem studied deals with repressive activities of the Red Guards and Zaofan in Hulunbuir league, their division into two fighting camps. The fourth objective is to examine the creation of the aimag revolutionary committee and its activities in 1968. Materials. The work analyzes three collections of official documents published in the PRC. The information thereof is supplemented with materials from works by Russian and foreign authors. The article provides a comparative analysis of events and facts, translates some terms from Mongolian and Chinese. Results. The introducing part the paper examines a prehistory of the 'Cultural Revolution', the ideological and political campaigns. Its main part studies the events of the 'Cultural Revolution' in the region. In July of 1966, a special working group arrived in Hailar on behalf of the CPC Northern Bureau. Members of this group were cadre Party workers from Hubei and Shanxi provinces. In September of 1966, Party Committee Secretary of Hulunbuir league Qi Junshan and Deputy Secretary Zhargal were dismissed from their posts. Red Guards appeared in Hulunbuir in August of 1966 and began organizing 'struggle meetings'. They actively recruited local Mongolian youth. In 1967, the Red Guards in Hulunbuir split into two opposing factions. They were confronting each other and for a while forgot about 'class enemies'. Activities of the Red Guards were out of control of the regional authorities, and the situation needed stabilization. In March of 1967, the State Council and the Central Military Commission of the People's Republic of China decided to create a military council in Hulunbuir league, also referred to as 'the first line to contain the Revolution and stimulate production'. On December 20, 1967, a revolutionary committee was formed in Hailar. In March of 1968, Shangmin, a loyal follower of Mao Zedong, became the leader of the revolutionary committee. Making false accusations, he intensified repressions against members of the 'Mongol Unification' faction. Conclusions. Political events in Hulunbuir league in 1965-1968 were directly related to the situation in the whole autonomous region and country. Repressions against members of the 'Mongol Unification' faction were a distinctive feature of the repressive policy in the region. Still, the appointments of cadre Party workers from central provinces are a poorly understood issue. So, the 'Cultural Revolution' in this territory of Inner Mongolia obviously has local features that require further scientific research.

Keywords: Cultural Revolution, Inner Mongolia, Hulunbuir league, party committee, Red Guards, repression, revolutionary committee

Acknowledgements. The reported study was funded by RFBR, project no. 19-39-90003, state reg. no. AAAA-A20-120052290030-0.

For citation: Tsybenov B. D., Ochirov Ts. S. From the Policy of 'Four Purges' to the Creation of Revolutionary Committees in Hulunbuir: Reconstructing the Beginnings of China's Cultural Revolution. Oriental Studies. 2020. Vol. 13(3): 493-505. (In Russ.). DOI: 10.22162/2619-09902020-49-3-493-505

\section{Введение}

Хулун-Буир - один из многонациональных регионов Внутренней Монголии КНР, с 2001 г. известный как городской округ Хулун-Буир, имеет богатую историю. Черной страницей в нее вписан период «культурной революции» (1966-1976 гг.). События обозримого прошлого не нашли подробного отражения в научных исследованиях, за исключением отрывочных сведений о Хулун-Буире в работах, освещаю- щих положение всего Автономного района Внутренней Монголии (далее - АРВМ) в изучаемый период. Между тем этот регион Китая, граничащий с Россией и Монголией, имел и имеет важное геополитическое значение в трехстороннем взаимодействии государств. Ход «культурной революции» в Хулун-Буире, несомненно, имел некоторые особенности, связанные с особым приграничным положением и населением региона. Таким образом, исследование значимых 
этапов новейшей истории Хулун-Буира представляется актуальным и своевременным. Авторы настоящей работы ранее обращались к различным аспектам исследуемой проблематики [Цыбенов 2018; Цыбенов, Очиров 2019; Очиров 2019а; Очиров 2019б; Цыбенов, Очиров 2020; Очиров 2020].

Необходимо также отметить, что основные этапы «культурной революции» во Внутренней Монголии, характерные и для Хулун-Буира, нашли отражение в работах отечественных [Мажинский 2014; Мажинский 2015; Балдано 2018] и зарубежных [Hyer, Heaton 1968; Heaton 1971; Sneath 1994; Tümen, Ju 1996; Жамсран, Эрдэнэбаяр, Алтанцэцэг 1996; Yang 2013] историков.

О проведении «культурной революции» в Хулун-Буире имеются данные в публикациях местных, баргутских краеведов [Dugaerzhabu 2007; Со 2010]. Понимая всю сложность малоизученной проблемы, авторы не претендуют на всесторонний детальный анализ поставленной проблематики.

\section{Постановка задачи}

Целью исследования является реконструкция политических событий в Хулун-Буирском аймаке АРВМ КНР в период с 1965 по 1968 гг. Наше исследование призвано осветить следующие моменты, имевшие место в изучаемый период: переход от политики «четырех пережитков» и «четырех чисток» к собственно «культурной революции», изменения в руководстве аймачного парткома и в целом в аймаке, разделение хунвейбинов и цзаофаней на две противоборствующие организации, деятельность военного комиссара Шанминя и начало репрессий, создание военных советов и ревкомов в Хулун-Буирском аймаке. В некоторых случаях приводятся монгольские и китайские термины, использовавшиеся в период «культурной революции». Исследование проведено на основе сравнительного анализа «культурной революции» в Хулун-Буирском аймаке и событий в г. Хух-Хото (административном центре Внутренней Монголии), а также и в целом в КНР.

\section{Материалы}

Основу работы составили «Материалы по истории КПК в Хулун-Буирском аймаке Автономного района Внутренняя Монголия КНР» под редакцией Чжан Фусяна
[Zhongguo 1989] и «Материалы по истории КПК в хошуне Восточная Новая Барга автономного района Внутренняя Монголия» под редакцией Цзин Чжуана [Zhongguo 1991], «Записки бедствий и страданий» под редакцией Алтан-Дэлихэй [Wasu zainan shilu 1999]. Они содержат официальные документы - указы, постановления, директивы. В них зафиксированы некоторые значимые события в регионе, имена региональных чиновников и партийных деятелей, сведения о создании новых органов власти и политических организаций, данные о начале репрессий в отношении руководства и населения Хулун-Буира.

Предыстория и начальный этап «культурной революции» в Хулун-Буире

Борьба с «четырьмя пережитками» $и$ проведение политики "четырех чисток" в начале 60-х г2. ХХ в.

Становление нового государства КНР - происходило в непростых условиях социально-экономических реформ и политико-идеологических кампаний. Их реализация на национальных окраинах непременно увязывалась с государственной национальной политикой. Господствовавшая в то время великоханьская идеология во многом противоречила интересам национальных меньшинств [Yang 2013: 1].

Ситуацию обостряли различные цивилизационные ценности кочевников-скотоводов и китайских земледельцев и активное заселение ханьцами территории АРВМ. В 1947 г. монголы составляли 1/4 от числа жителей АРВМ, в 1960 г. они составили 1/9 часть от всего населения автономного района. Эта негативная тенденция не могла не вызвать у многих монголов и их лидеров ответную реакцию в виде «монгольского национализма» [Hyer, Heaton 1968: 117; Heaton 1971: 4].

Поэтому центральное правительство особенно беспокоила деятельность руководства АРВМ. Не осталась незамеченной пекинским руководством критика национальной политики КПК, высказанная лидером АРВМ Уланху в сентябре 1956 г. на VIII съезде КПК [Бакаева, Юша 2019: 181].

Очевидно, уже тогда центральное правительство взяло его на заметку как потенциально опасного, независимого в своих суждениях национального руководителя. 
Начиная с 1957 г. государственная национальная политика быстро меняется не в лучшую сторону. Одним из ее негативных проявлений стала кампания борьбы с «четырьмя пережитками», стартовавшая в августе 1964 г. Под «четырьмя пережитками» понимались «старые идеи, старая культура, старые обычаи и привычки». Эта кампания нанесла тяжелый удар по этнокультурной специфике национальных меньшинств [Новичков 2017: 49-50].

Не стал исключением и Хулун-Буирский аймак (далее - ХБА) АРВМ, населенный монголами (баргутами, бурятами, олетами, хорчинами), даурами, эвенками-солонами, эвенками-орочонами, русскими. Есть мнение, что до начала «культурной революции» ХБА находился на завершающей стадии кампании борьбы с «четырьмя пережитками» [Zhongguo 1991: 53]. На наш взгляд, оно не совсем верно, поскольку вышеотмеченная кампания началась в августе 1964 г. и не могла завершиться так скоро. Эта борьба органично вписалась в идейную структуру «культурной революции» и была продолжена в ее рамках.

Другой идейно-политической кампанией была «политика четырех чисток» (монг. dörbe-yi čeberlekü), берущая свое начало с пленума ЦК КПК в сентябре 1962 г. В ее основе лежала чистка партийных рядов от скомпрометировавших себя кадровых работников (ганьбу). В ХБА эта кампания проводилась специальными рабочими группами. Они выезжали в скотоводческие производственные площадки и бригады, проводили там собрания, на которых разъясняли необходимость борьбы с состоятельными и отошедшими от революционной борьбы ганьбу. Известно, что в октябре 1965 г. состоялось такое собрание на скотоводческой производственной площадке под названием «1 мая» в Новой Барге [С̆о 2010: 313].

К тому времени преследование центральным правительством Уланху и его сторонников находилось в активной фазе. В конце 1965 г. они потеряли свои должности [Мажинский 2015: 139]. Сведениями о смещении с постов руководства ХБА в 1965 г. мы не располагаем. Хотя до начала «культурной революции» большой резонанс в аймаке и в целом в автономном районе получило дело о партийных фракциях, и ряду деятелей были вынесены обвини- тельные приговоры. Это дело, как и другие региональные дела - «206», «комиссия из 43 чел.», «До-На-Сун», находилось в поле зрения руководства АРВМ. Суть дела, на наш взгляд, состояла в наличии двух фракций Народно-революционной партии Внутренней Монголии (далее — НРПВМ) в Хулун-Буире: nigetgekü nam (досл. 'партия объединения') и ünen nam (досл. 'партия справедливости'). Слово nam в данном контексте мы переводим как «фракция». Обвинения в отношении членов указанных фракций были основаны на идее объединения Внутренней и Внешней Монголии, а также на неправильном понимании сути национальной политики КНР.

Для расследования этого дела партийное руководство АРВМ направило в ХБА трех секретарей парткомов - Ван Цзайтяня, Билэгбатора и Чжан Синъюаня. Дата их отправки в Хулун-Буир не известна. Выяснено лишь, что они сумели определить имевшиеся противоречия и виновных лиц, и вынести справедливые, взвешенные решения [Tümen, Ju 1996: 236]. Таким образом, борьба властей с «зараженными национализмом», «черными элементами» имела место в ХБА до «культурной революции».

Появление и деятельность революционных организаций в Хулун-Буире и изменения в партийном руководстве в 1966 2.

Объявление о проведении «культурной революции» на территории под руководством Мао Цзэдуна от 18 апреля 1966 г. встретило ожидаемое сопротивление Уланху и его окружения. Они в свою очередь решили провести «мягкую культурную революцию» и лишили должностей отдельных промаоистских чиновников [Мажинский 2014: 160-161].

В то же время развернулась кампания критики Уланху, совмещавшего несколько должностей: первый секретарь парткома АРВM, председатель народного комитета автономного района, второй секретарь Северокитайского бюро, вице-премьер Госсовета КНР. Против него были выдвинуты ложные обвинения, началась борьба под лозунгом «Атакуем антиреволюционную партийную группировку Уланху». Массовой проверке и гонениям подверглись деятели культуры, главы хошунов и городов, аймаков. Все они были названы «членами 
темной банды Уланху», «сепаратистами», «ревизионистами». Среди пострадавших выделялись представители интеллигенции, которых обвиняли в шпионаже и просоветской пропаганде [Li 2009: 116; Ли Фэн Мин 2017: 282].

Особая национальная политика, проводившаяся в АРВМ с самого начала «культурной революции», дискредитировала идею единства наций в регионе и нанесла ощутимый удар национальным меньшинствам APBM [Wu 2012: 512].

Летом 1966 г. в АРВМ были направлены тысячи хунвейбинов-ханьцев из Пекина, Шанхая. 10 августа 1966 г. в г. Хух-Хото имели место крупные столкновения между хунвейбинами и сторонниками Уланху. Погибло много людей [Автономный район 1980: 111; Жамсран, Эрдэнэбаяр, Алтанцэцэг 1996: 109].

Тем временем обстановка в ХБА была относительно спокойной. По некоторым данным, в июле 1966 г. в аймаке появилась организованная рабочая группа из 31 чел., прибывшая для продвижения идей «культурной революции» в народные массы. Эта группа, состоявшая из выходцев провинций Хубэй и Шаньси, была направлена по решению Северного бюро КПК [Zhongguo 1989: 127].

По нашему предположению, члены этой группы могли быть партийными кадровыми работниками, а не рядовыми хунвейбинами. Известно, что партийных деятелей - ханьцев из провинций Хубэй и Шаньси направляли в аймаки АРВМ еще в период кампании «четырех чисток». С началом «культурной революции» их стали продвигать на руководящие должности [Нао 2009]. Смена монгольской элиты на ханьскую была одной из важных задач, успешно решаемых центральным правительством [Балдано 2018: 42-43].

Что касается прибытия хунвейбинов, то летом 1966 г. их первые отряды прибыли в Хайлар [Li 1996: 102; Очиров, Цыбенов 2020: 71]. Возможно, в ХБА они появились позже, чем в Хух-Хото, Баотоу и других крупных городах АРВМ. Достоверно установлено, что отряды хунвейбинов были направлены в Хулун-Буир после участия в «параде» в Пекине, прошедшего 18 августа 1966 г. [Автономный район 1980: 112].

Для проведения деятельности на местах часть этих отрядов могла быть направлена в хошуны и сомоны. Их пребывание там было кратковременным, уже в сентябре 1966 г. официально был наложен запрет на выезд хунвейбинов в сельские местности. Тем не менее, вероятно, под их влиянием в августе 1966 г. в скотоводческих производственных площадках и бригадах создаются так называемые «комитеты» (кит. 委员会 wei yuan hui). В комитет скотоводческой производственной бригады входило 5-7 членов, комитет бригады состоял из 3-5 чел. Организовав малоимущие аратские массы, они стали устраивать собрания борьбы (монг. temčel-un qural). На них совершались гонения на состоятельных скотоводов. Их раздевали до нательного белья, заставляли стоять сгорбившись, обмазывали лица черной краской, били, лишали гражданских прав [С̆о 2010: 314].

В то же время отряды хунвейбинов активно рекрутировали в свои ряды местную молодежь - школьников и студентов ХБА. К тому времени они практически не учились. После мая 1966 г. были приостановлены занятия, либо они продолжались частично [Cheng 1996: 992; Хu 2009: 223].

В целом отличительной чертой движения хунвейбинов в АРВМ, по мнению западных исследователей, было то, что интеллигенты-ханьцы пострадали в меньшей степени, чем интеллигенция в других китайских провинциях. Это объясняется тем, что во Внутренней Монголии основное внимание революционных организаций было уделено так называемому «монгольскому национализму» [Sneath 1994: 10].

Особую энергичность в деле борьбы с «черными элементами» проявил Шанминь, военный комиссар ХБА. Он называл филиал НРПВМ в ХБА «фракцией объединения монгольского народа» (сокр. «фракция объединения»). В отношении этой фракции им были выдвинуты ложные обвинения, такие как «клан Чингисхана», «партия независимости», «группа по объединению Внешней и Внутренней Монголии», «повстанцы» и др. Всего таких ложных обвинений насчитывалось 202. Репрессии в отношении членов «фракции объединения» были начаты им задолго до официального начала кампании против НРПВМ [Wasu zainan shilu 1999: 155].

6 августа 1966 г. в п. Амгалан Восточного хошуна Новой Барги под руководством 
Шанминя было организовано собрание с участием около 1 тыс. чел. Секретарь хошунного парткома, его заместитель и ряд других руководителей были объявлены врагами партии и государства. Позже, в сентябре 1966 г. они были признаны главными пособниками антиреволюционной деятельности [Zhongguo 1991: 53, 59].

Шанминь, очевидно, принадлежал к числу сторонников Дэн Хайцина и Кан Шэна - проводников «культурной революции» в АРВМ. До начала «культурной революции» он претворял в жизнь политику «четырех чисток». Если в Хух-Хото многие высокопоставленные военные чины, в частности Лю Чан, были на стороне Уланху, и они успешно боролись с хунвейбинами, то в ХБА военный комиссар изначально поддерживал идею «культурной революции». Поэтому ситуация в аймаке, по всей видимости, отличалась от событий в Хух-Хото в сторону заметного усиления позиций сторонников «культурной революции», в чьих рядах были военные. С другой стороны, партийный комитет Внутренней Монголии, после отстранения Уланху от должности председателя КПК АРВМ на несколько месяцев, находился в руках сторонников «культурной революции». Председателем КПК АРВМ стал бывший партийный секретарь провинции Хэбэй и г. Тяньцзиня Се Сюэгун [Мажинский 2015: 139], усиливший позиции сторонников «культурной революции» в Хух-Хото во главе с заместителем председателя КПК АРВМ Гао Цзиньминем.

21 августа 1966 г. партком АРВМ поставил вопрос о несоответствии должностям секретаря парткома ХБА Ци Цзюньшаня и его заместителя Жаргала. Они должны были признать свои ошибки и покинуть руководящие посты. Учитывая непреклонное исполнения директив вышестоящей партийной инстанции, можно предположить, что их отставка состоялась в тот же день. Новые назначения в партийном руководстве ХБА состоялись 13 сентября 1966 г.: секретарем парткома ХБА стал Хуашан, глава организованной рабочей группы; его заместителями - Дун Циминь и Синь Анмин, члены организованной рабочей группы [Zhongguo 1989: 127].

Нововведения в парткоме были продолжены в октябре 1966 г. Так, 24 октября
1966 г. согласно директиве парткома АРВМ аймачный партком был упразднен, и вместо него был создан временный комитет КПК в ХБА. Большинство членов в новом парткоме составили лица, бывшие ответственными за проведение политики «четырех чисток» в аймаке [Fu 1996: 161]. Под их руководством в ноябре 1966 г. в ХБА стали создаваться массовые революционные организации [Zhongguo 1989: 593]. Их основу, очевидно, составляли прибывшие в Хулун-Буир отряды хунвейбинов-ханьцев. Как известно, они в принудительном порядке проводили мобилизацию в свои ряды молодых монголов. Эти мероприятия проходили по всему АРВМ. В конце декабря 1966 г. создаются отряды цзаофаней (революционных рабочих), и в Хух-Хото появляются две основные организации хунвейбинов и цзаофаней: «Третий штаб Хух-Хото» (объединивший наиболее экстремистские слои учащихся и рабочих) и «Ляньше» (умеренные слои, в значительной степени состоявшие из монголов) [Автономный район 1980: 112-114]. Можно предположить, что их ячейки появились и в Хулун-Буире. По некоторым данным, в эвенкийском хошуне ХБА местные хунвейбины и цзаофани разделились на две организации: «ляньхэ» и «дунсы» [Очиров, Цыбенов 2020: 69]. Такое же деление на две части (кит. 排 pai - взвод; линия) было и в баргутских хошунах [С̆о 2010: 315]. Поскольку раскол хунвейбинов и цзаофаней на две организации в вышеотмеченных хошунах произошел весной 1967 г., то вероятно, что зимой 1966/1967 гг. его в Хулун-Буире еще не было.

Противостояние хунвэйбинов и цзаофаней в 1968 г. как фактор дальнейшей дестабилизации ситуации

В начале 1967 г. «культурная революция» в КНР приобрела радикальный характер. Начало захвата власти хунвейбинами и цзаофанями было положено так называемым январским штормом, когда в Шанхае началась серия захватов и разгромов. В частности, были разгромлены редакции газет «Вэньхуй бао», «Цзефан жибао». Неделю (9-14 января 1967 г.) длился штурм Шанхайского горкома КПК [История 2004: 223].

В АРВМ захват власти хунвейбинами и цзаофанями начался в январе-феврале 
1967 г. и получил название «Февральское дело оппозиционного направления во Внутренней Монголии». Суть дела состояла в том, что несколько высокопоставленных чиновников парткома АРВМ пытались противодействовать «левым» эксцессам «культурной революции». В итоге в феврале-марте 1967 г. по всему автономному району происходили столкновения между революционными организациями и органами власти на местах [Li 2009: 116].

Вслед за кровавыми событиями в Хух-Хото, произошедшими в январе-феврале 1967 г., в ХБА в феврале 1967 г. активизировались цзаофани, совершившие атаки на местные органы власти, парткомы. В ряде мест они захватили власть и, устраивая беспорядки, приостановили на время деятельность органов власти [Fu 1996: 161]. В частности, пострадало руководство орочонского хошуна ХБА. После «митинга борьбы» руководители хошуна - Мэргэн-Далай, Найрал и другие были подвергнуты публичным унижениям [Hequn 2006: 318].

Поскольку в целом ситуация в аймаке выходила из-под контроля, Госсовет КНР и Центральный военный комитет КНР в марте 1967 г. приняли решение о создании в аймаке военного совета, также именуемого как «первая линия по сдерживанию революции и стимулированию производства». Командиром военного совета был назначен Ван Цзянь, его заместителем - Чжан Шоуцюань [Zhongguo 1989: 138].

Обстановку в аймаке удалось стабилизировать, но ненадолго. Не повлияла на ситуацию и директива ЦК КПК от 13 апреля 1967 г. «Решение о правильном разрешении вопросов во Внутренней Монголии». К тому времени, 7 апреля 1967 г., в Хух-Хото была введена 21-я армия НОАК провинции Шэньси под командованием Дэн Хайцина [Мажинский 2014: 165].

Однако столкновения между маоистами и сторонниками Уланху продолжались до начала лета 1967 г. В г. Хайлар сформировались две массовые революционные организации, и началась междоусобная борьба. Административно-управленческий аппарат аймака продолжал находиться в парализованном состоянии. Вся полнота власти находилась в руках массовых революционных организаций. 11 апреля 1967 г. согласно решению парткома АРВМ были уволены с должностей секретарь парткома ХБА Хуашан, его заместитель Дун Циминь и ряд других партийных чиновников. Вместо них были назначены члены специальной рабочей группы, направленные Северным бюро КПК. В то же время началась критика бывших партийных лидеров аймака - Ци Цзюньшаня, Жаргала, Ван Линьчжуна, Сулиня. Они были объявлены руководителями «сепаратистской монгольской группировки», «антипартийной группой предателей во главе с Ци, Жаргалом и Ваном» [Zhongguo 1989: 139]. Известно, что вышеуказанные лица находились в местах заключения с конца 1967 г. по начало 1972 г. В 1968-1969 гг. они были под надзором военных. В середине июня 1970 г. Ци Цзюньшань, Жаргал и ряд других бывших деятелей были направлены на ремонт железной дороги в местности Лицзишань (север провинции Хэйлунцзян). После 11 месяцев принудительных работ они были возвращены в г. Хайлар [Dugaerzhabu 2007: 188-190].

В мае-июне 1967 г. в ХБА противостояние между двумя массовыми революционными организациями вылилось в погромы: 17 мая 1967 г. - почтово-телеграфного отделения, 3 июня - партийной школы, 25 июня - мясокомбината. В ходе беспорядков были убиты заместитель секретаря аймачного парткома Ганжав, начальник секретного отдела Ешиндагба. В то же время военные пытались стабилизировать ситуацию. Так, в июне 1967 г. ими был создан комитет безопасности, по сути руководивший действиями аймачного парткома и сосредоточивший в своих руках все три ветви власти (законодательную, судебную и исполнительную) [Zhongguo 1989: 321]. Есть мнение, что в целом этот год (1967) прошел относительно спокойно для таких категорий обвиняемых, как «помещики» и «кулаки». Хунвейбины и цзаофани, разделившись на две группы, дрались между собой. Они обвиняли друг друга в неправильных взглядах на проведение «культурной революции» [Čo 2010: 315].

20 декабря 1967 г. в Хайларе был создан ревком ХБА. Военный совет, называемый «первой линией по сдерживанию революции и стимулированию производства», был расформирован. Члены специальной рабочей группы от Северного бюро КПК, вре- 
менно занимавшие руководящие должности в аймачном парткоме, были распущены [Cao 1986: 12].

Ревкомы и усиление репрессий в аймаке: борьба с НРПВМ и классовые чистки

После создания ревкома в Хайларе стали создаваться местные ревкомы во всех хошунах и городах ХБА. Так, 28 января 1968 г. был создан ревком даурского автономного хошуна Морин-Дава [Цыбенов 2018: 207].

Председатели местных ревкомов и их заместители назначались аймачным ревкомом. Структура ревкомов была следующей: главным органом власти был пленум ревкома. Текущие дела решал Постоянный комитет. Его, в свою очередь, возглавляло «руководящее ядро». В ревком входили 3 подкомитета, ответственные за политическую, производственную и массовую работу. Каждый подкомитет имел несколько отделов [История 2004: 229].

8 марта 1968 г. председателем ревкома ХБА стал военный комиссар Шанминь, его заместителем - Чжан Шоуцюань. В состав «руководящего ядра» вошли Ван Синцзюнь, Лифэн, Чжао Дэцай [Zhongguo 1989: 140-141].

В апреле 1968 г. во Внутренней Монголии было сфабриковано дело об антигосударственной деятельности НРПВМ. Тогда же появилось и дело о фракции объединения монголов в ХБА. Были подняты старые дела периода кампании «четырех чисток», ставшие в руках Шанминя «явными доказательствами» причастности многих лиц к подпольной антигосударственной деятельности. Члены фракции объединения именовались «старыми друзьями Уланху», a eе деятельность, как указывал Шанминь, на протяжении 20 лет была направлена против интересов государства, Мао, социализма. Репрессии в ХБА были достаточно серьезными, много людей погибло или стали инвалидами. По некоторым данным, из 31 тыс. членов различных партий (сюда включаются и представители фракций объединения и справедливости) в ХБА были репрессированы 14891 чел. В тюремном заключении находились 14329 чел., из них только 56 чел. прошли через полный судебный процесс. Погибло 2307 чел. - членов НРПВМ [Wasu zainan shilu 1999: 92].

Борьба с НРПВМ в ХБА проходила под лозунгами «Врагами народа является антипартийная группа во главе с Уланху и Хафэньга», «Размозжим собачьи головы Лю Шаоци, Уланху, Бимбы, Сэрдамбы!». В последнем случае речь идет о партийных лидерах Новой Барги - Бимбе и Сэрдамбе, находившихся в тюремном заключении еще с начала 1968 г. В ходе кампании против «черной банды Уланху» пострадало также много чиновников и интеллигентов - лиц даурской национальности [Mode' ertu 2018: 183-186].

Наряду с борьбой против членов НРПВМ продолжилась чистка классовых рядов. В 1968 г. «классовые враги» в ХБА были обвинены в трех противодействиях: 1) политике партии; 2) линии председателя Мао; 3) общественному правопорядку. Они были разделены на следующие категории: инакомыслящие богачи (terseleküü bayan), хозяева скота (mal-un ejen), народные раскольники (ündüsüten-ü qaүačayulaүči), имеющие оружие и боеприпасы (puu jebseg-tei bayiүsan).

В административных центрах хошунов и сомонов функционировали так называемые «учреждения диктатуры народных масс» (olan tümen-ü darungyuyilaqu yajar), куда доставлялись обвиняемые. Эти учреждения также выполняли роль своеобразных мест лишения свободы. Во время второй конфискации имущества у «богачей» в 1968 г. (первая конфискация состоялась в сентябре 1966 г.) забрали все движимое и недвижимое имущество. Люди, подвергшиеся гонениям, остались в одной летней одежде. Лишь в октябре 1968 г. «учреждения диктатуры народных масс» стали выдавать им теплую одежду.

К тому времени состав массовых революционных организаций в ХБА, очевидно, был уже смешанным. Наряду с ханьцами имелись и монголы. Так, среди особо усердствовавших хунвейбинов и цзаофаней в Новой Барге были Чжан Цзянь, Бай Лун, Х. Жаргал, Улаан-Одсор, Лунтай, Бао Чиншан. Среди популярных вопросов, задаваемых на допросах, были следующие: Какую работу выполнял в пользу Японии? Есть оружие? Являешься ли членом другой народной партии? Готовил ли побег в Халха-Монголию? Последний вопрос был актуален, поскольку имели место случаи перехода скотоводов на территорию МНР. Например, баргут Добдон, вызволив жену, 
находившуюся в заключении в «учреждении диктатуры народных масс», бежал с ней в МНР. После этого побега все скотоводческие бригады, кочевавшие в районе китайско-монгольской границы, были перемещены вглубь аймака, в лесостепные районы Прихинганья. Побег Добдона еще более усилил гонения на «классовых врагов» [С̆о 2010: 316-317].

В сентябре 1968 г. председатель ревкома ХБА Шанминь подготовил доклад об успешной борьбе против членов фракции объединения [монголов]. Доклад предназначался для Линь Бяо и Цзян Цин - основных проводников «культурной революции». В качестве подозреваемых в членстве во фракции объединения проходило много представителей национальных меньшинств Хулун-Буира. Признательные показания выбивались у обвиняемых путем жестоких, порой изощренных пыток. При этом Шанминь указывал, что для выявления преступных элементов и членов фракции объединения достаточно признания виновности двух или трех товарищей обвиняемого [Wasu zainan shilu 1999: 92].

Осенью 1968 г. при содействии ревкома ХБА в аймаке активно функционируют «группы изучения произведений Мао Цзэдуна». Усиливается роль китайского языка во всех сферах жизни. В школах учителя-монголы опасались говорить на родном языке, боясь подвергнуться гонениям [Буяров 2016: 41].

Продолжилась чистка классовых рядов. В ноябре 1968 г. состоялось 3-е расширенное пленарное заседание ревкома APBM, на котором был поддержан крайне правый политический курс - «классовая чистка». Большой резонанс в АРВМ и ХБА получило «особое дело Ван Хайшаня», для

\section{Сокращения}

АРВМ - Автономный район Внутренняя Монголия

кит. - китайский язык

\section{Литература}

Автономный район 1980 - Автономный район Внутренняя Монголия Китайской Народной Республики / под общ. ред. Б. Ширендыба, М. И. Сладковского. М.: Наука, 1980. 157 с. расследования которого в ноябре 1968 г. была направлена в Хулун-Буир комиссия из Пекинского военного округа. Это дело находилось под личным контролем Кан Шэна, Цзян Цин и Чжоу Вэньюаня [Tümen, Ju 1996: 58].

Экстренная встреча военкома ХБА и представителей местных органов власти прошла в декабре 1968 г. На ней было объявлено о проведении «классовой чистки» [Hequn 2006: 318]. Так в конце 1968 г. подходил к своему завершению третий год «культурной революции». Борьба с «черными элементами», развязанная центральным правительством КНР, подходила к критической точке.

\section{Выводы}

Как и во всем Китае, кампания «четырех чисток» (с 1962 г.) и борьба с «четырьмя пережитками» (с 1964 г.) в ХБА плавно перетекла в «культурную революцию». Особенностью аймака была борьба с фракцией «объединения» НРПВМ, также начавшаяся до «культурной революции». Сделано предположение о более позднем появлении (после 18 августа 1966 г.) отрядов хунвейбинов в Хулун-Буире. Как и в Хух-Хото, в ХБА хунвейбины и цзаофани разделились на две враждующие группы. Установлено, что в июле 1966 г., согласно распоряжению Северного бюро КПК, в Хайлар прибыла организованная рабочая группа, в сентябре того же года сменившая руководство аймачного парткома. В августе 1966 г. в аймаке создаются «комитеты», устраивавшие гонения на «классовых врагов». Большую роль в организации репрессий играет Шанминь, военный комиссар ХБА. В марте 1968 г. он становится председателем аймачного ревкома и усиливает гонения на членов фракции «объединения» НРПВМ.

монг. - монгольский язык

НРПВМ - Народно-революционная партия Внутренней Монголии

ХБА - Хулун-Буирский аймак

Балдано 2018 - Балдано М. Н. Национальная политика Китая в отношении монгольских народов // Наука и образование сегодня. 2018. № 12 (35). С. 40-43.

Бакаева, Юша 2019 - Бакаева Э. П., Юша Ж. М. 
Современная этническая идентичность ойратов и тувинцев Китая: к вопросу о специфике национального вопроса в КНР [электронный ресурс] // Новые исследования Тувы. 2019. № 4. URL: https:// nit.tuva. asia/nit/article/view/893 (дата обращения: 20.04.2020.). DOI: $10.25178 /$ nit.2019.4.15

Буяров 2016 - Буяров Д. В. Национальная политика Китая в конце 1950-х - конце 1970-х гг. // Историческая и социально-образовательная мысль. 2016. Т. 8. № 1-1. С. 3943.

Жамсран, Эрдэнэбаяр, Алтанцэцэг 1996 Жамсран Л., Эрдэнэбаяр Y, Алтанизэฺэ Н Хятад дахь монголчууд (= Монголы Китая). Улаанбаатар: Хэвлэлийн «Сүхбаатар» компанид хэвлэв, 1996. $182 \mathrm{c}$.

История 2004 - История Северо-Восточного Китая XVII-XX вв. Книга 3. Северо-Восточный Китай в 1945-1978 гг. / гл. ред. В. Л. Ларин, отв. ред. Г. П. Белоглазов. Владивосток: Дальнаука, 2004. 344 с.

Ли Фэн Мин 2017 - Ли Фэн Мин. Улаанхүугийн үндэстэн ба нэгдмэл фронтын онол, практикийн тухай судалгаа (= Национализм и Объединенный фронт в теоретических и практических взглядах Уланху). Улаанбаатар: Бэмби сан, 2017. 346 с.

Мажинский 2014 - Мажинский С. В. Социально-экономическое и политическое развитие Внутренней Монголии в контексте модернизации Китая: дис. ... канд. ист. наук. Томск, 2014. 214 с.

Мажинский 2015 - Мажинский С. В. Центральное правительство Китая и автономный район Внутренняя Монголия в 1966-1969 гг.: от диалога к политической борьбе // Вестник Томского государственного университета. 2015. № 401. С. 139-144.

Новичков 2017 - Новичков В. C. Сущность национальной политики в КНР в период деструкции (1956-1978 гг.) // Вестник Томского государственного университета. История. 2017. № 45. С. 48-54.

Очиров 2020 - Очиров Ц. С. К изучению начального этапа «культурной революции» в автономном районе Внутренняя Монголия // Власть. 2020. Т. 28. № 1. С. 251-256.

Очиров 2019а - Очиров Ц. С. К изучению периода культурной революции» в Хулун-Буире Внутренней Монголии // Иркутский историко-экономический ежегодник: 2019. Иркутск: Изд-во БГУ, 2019. С. 375-380. DOI 10.17150/978-5-7253-3001-4.50
Очиров 20196 - Очиров Ц. С. Национальные меньшинства Хулун-Буира в период «культурной революции» в КНР: зарубежная историография проблемы // Гуманитарный вектор. 2019. Т. 14. № 3. С. 64-70.

Цыбенов 2018 - Цыбенов Б. Д. Социально-политическое развитие даурского автономного хошуна Морин-Дава в 1958-1984 гг. // Власть. 2018. № 7. С. 205-211.

Цыбенов, Очиров 2019 - Цыбенов Б. Д., Очиров Ц. С. Национальные меньшинства Хулун-Буира в период «культурной революции» в КНР: российская историография проблемы // Вестник Бурятского научного центра Сибирского отделения Российской академии наук. 2019. № 1 (33). С. 108-115. DOI 10.31554/2222-9175-2019-33-108-115

Цыбенов, Очиров 2020 - Цыбенов Б. Д., Очиров Ц. С. Глазами очевидцев: мемуары и устная история // Вестник Бурятского научного центра Сибирского отделения Российской академии наук. 2020. № 1 (37). C. 68-76. DOI 10.31554/2222-9175-2020-37-68-76

Cao 1986 - Cao Li. Hulunbeier meng qing (= Ситуация в Хулун-Буирском аймаке). Hailaer: Neimenggu renmin chubanshe, 1986. 504 p.

Cheng 1996 - Cheng Zhi. Molidawa dawo'erzu zizjiqi zhi (= Обзор даурского автономного хошуна Морин-Дава). Huhehaote: Neimenggu renmin chubanshe, 1996. $1998 \mathrm{p}$.

Čo 2010 - Čo Oršon. Emči Sangja-yin ergičegülül // Baryu sudulul-un ugulel-n teguberi (nige) / Kulun Byir-n baryu sudulul-un neyigemlig-n šine baryu jegun qošiun-u ajillaqu ajar nayiraulaba (= Изменения в жизни доктора Санжа // Исследования баргутов. Сборник статей. Вып. 1). Hohhot: Öbőr Mongyol-un keblel-un soyol-un keblel-un qoriy-a, 2010. T. 1. Pp. 312-322.

Dugaerzhabu 2007 - Dugaerzhabu. Cangsang suiyue (= Период невзгод). Hulunbei'er: Neimenggu chubanshe, 2007. 264 p.

Fu 1996 - Fu Quan. Ewenke zizhi qizhi (= Эвенкийский автономный хошун). Beijing: Zhongguo chengshi chubanshe, 1996. 1043 p.

Hao 2009 - Hao Weimin. Wenge zhong zaiqu Neimenggu (= Внутренняя Монголия как регион, наиболее пострадавший от «культурной революции») // Southern Mongolian comment on current affairs. February 5, 2009. URL: http://smglnc.blogspot.com/2009/02/ blog-post_8153.html (дата обращения: 20.06.2020). (In Chin.)

Heaton 1971 - Heaton W. Inner Mongolia: "Local nationalism" and the "cultural revolution" // 
Mongolia Society. 1971. Vol. 10. No. 2 (19) Pp. 2-34.

Hequn 2006 - Hequn. Huangjie yu xiao minzu shengcun (= Окружающая среда и выживание малых народов). Beijing: Shehui kexue wenxue chubanshe, 2006. $582 \mathrm{p}$.

Hyer, Heaton 1968 - Hyer P., Heaton W. The Cultural Revolution in Inner Mongolia // The China Quarterly. 1968. No. 36. Pp. 114-128.

Li 2009 - Li Dezhu. Neimenggu zizhuqu gaikuang (= Общая ситуация в автономном районе Внутренняя Монголия). Beijing: Minzu chubanshe, 2009. $667 \mathrm{p}$.

Li 1996 - Li Wenxiu. Gangzhu'er miao waiji (= Заметки о монастыре Ганчжур). Hailaer: Neimenggu renmin chubanshe, $1996.356 \mathrm{p}$.

Mode'ertu 2018 - Mode'ertu. Jiefang zhanzheng zhongde dawo'er zu (= Даурский народ в Ocвободительной войне). Hailaer: Neimenggu renmin chubanshe, 2018. $520 \mathrm{p}$.

Sneath 1994 - Sneath D. The Impact of the Cultural Revolution in China on the Mongolians of Inner Mongolia // Modern Asian Studies. 1994. Vol. 28. No. 2. Pp. 409-430.

Tümen, Ju 1996 - Tümen, Ju Dung Li. Kan Sheng kiged Öbör Mongyol-un arad-un qubisqaltu nam-un kilis kereg (= Кан Шэн и ложное

\section{References}

Alatan Delihai (ed.) Notes of Disaster and Sufferings. Hohhot: Yuanfang Publ., 1999. 393 p. (In Chin.)

Bakaeva E. P., Yusha Zh. M. Contemporary ethnic identities of China's Oirats and Tuvans: specificity of the PRC's national question revisited. The New Research of Tuva. 2019. No. 4. Available at: https:// nit.tuva.asia/nit/article/ view/893 (accessed: April 20, 2020.). (In Russ.) DOI: $10.25178 /$ nit.2019.4.15

Baldano M. N. China's ethnic policy towards Mongolic peoples. Science and Education Today. 2018. No. 12 (35). Pp. 40-43. (In Russ.)

Buyarov D. V. China national policy in the late 1950s to the late 1970s. Historical and Social Educational Ideas. 2016. Vol. 8. No. 1-1. P. 3943. (In Russ.)

Cao Li. Situation in Hulun Buir Aimag Revisited. Hailar: Inner Mongolia People's Publ., 1986. 504 p. (In Chin.)

Cheng Zhi. A Review of Morin Dawa Autonomous Banner. Hohhot: Inner Mongolia People's Publ., 1996. 1998 p. (In Chin.)

Čo Oršon. Changes in Doctor Sanja's life. In: обвинение Народно-революционной партии Внутренней Монголии). Begejing: Ündüsüten-ü keblel-ün qoriy-a, 1996. 594 p.

Wasu zainan shilu 1999 - Wasu zainan shilu / Alatan Delihai zhubian (= Записки о бедствиях и страданиях / отв. ред. Алатан Дэлихай). Huhehaote: Yuanfang chubanshe, 1999. 393 p.

$\mathrm{Wu} 2012$ - Wu Shougui. Ewenke zu shehui (= Эвенкийское общество). Beijing: Minzu chubanshe, 2012. $548 \mathrm{p}$.

Xu $2009-X u$ Zhanjiang. Zhongguo buliyate ren (= Буряты Китая). Hailaer: Neimenggu renmin chubanshe, 2009. $356 \mathrm{p}$.

Yang 2013 - Yang Haiying. Ulanhu a Nationalist Persecuted by the Chinese Communists. Nagoya: Association for Afro-Eurasian Inner Dry Land Civilization Studies, 2013. 102 p.

Zhongguo 1989 - Zhongguo gongchandang Neimenggu zizhiqu Hulunbeier mengzuzhi shi ziliao (9.1945-12.1987) / Zhang Fuxiang zhubian. Hailaer: Neimenggu renmin chubanshe, $1989.777 \mathrm{p}$.

Zhongguo 1991 - Zhongguo gongchandang Neimenggu zizhiqu Xinbaerhu zuoqi zuzhi shi ziliao (4.1948-12.1989) / Jing Zhuang zhubian. Hailaer: Neimenggu renmin chubanshe, $1991.131 \mathrm{p}$.

Barghut (Barga) Studies. Collected Papers. Vol. 1. Hohhot: Inner Mongolia Culture Publ., 2010. Pp. 312-322. (In Mong.)

Dugaerzhabu. The Period of Hardships. Hulunbuir: Inner Mongolia Publ., 2007. 264 p. (Chin.)

Fu Quan. Ewenki Autonomous Banner. Beijing: China City Press, 1996. 1043 p. (In Chin.)

Hao Weimin. Inner Mongoliya as a region worstaffected by the 'Cultural Revolution'. On: Southern Mongolian Comment on Current Affairs. February 5, 2009. Available at: http:// smglnc.blogspot.com/2009/02/blog-post_8153. html (accessed: June 20, 2020). (In Chin.)

Heaton W. Inner Mongolia: 'local nationalism' and the 'cultural revolution'. Mongolia Society. 1971. Vol. 10. No. 2 (19). Pp. 2-34. (In Eng.)

Hequn. Environment and Survival of Ethnic Minorities. Beijing: China Social and Literary Press, 2006. 582 p. (In Chin.)

Hyer P., Heaton W. The Cultural Revolution in Inner Mongolia. The China Quarterly. 1968. No. 36. Pp. 114-128. (In Eng.)

Jing Zhuang (ed.) New Barga Left Banner of the Inner Mongolia Autonomous Region (China): Materials of the Local CCP Organization, April 
1948 - December 1989. Hailar: Inner Mongolia People's Publ., 1991. 131 p. (In Chin.)

Larin V. L., Beloglazov G. P. (eds.) History of Northeast China: $17^{\text {th }}-20^{\text {th }}$ Centuries. Vol. 3: Northeast China, 1945-1978. Vladivostok: Dalnauka, 2004. 344 p. (In Russ.)

Li Dezhu. Inner Mongolia Autonomous Region: Overall Situation. Beijing: Nationalities Press, 2009. 667 p. (In Chin.)

Li Feng Ming. Ulanhu: Nationalism and Unification Front in His Theoretical and Practical Approaches. Ulaanbaatar: Bembi San, 2017. 346 p. (In Mong.)

Li Wenxiu. Essays on Ganjur Monastery. Hailar: Inner Mongolia People’s Publ., 1996. 356 p. (In Chin.)

Mazhinsky S. V. Chinese Government and the Inner Mongolia Autonomous Region during 1966-1969: from dialogue to political struggle. Tomsk State University Journal. 2015. No. 401. Pp. 139-144. (In Russ.)

Mazhinsky S. V. Inner Mongolia: Socioeconomic and Political Development of the Region in the Context of China's Modernization. Cand. Sc. (history) thesis. Tomsk, 2014. 214 p. (In Russ.)

Mode'ertu. Daur People in the Liberation War. Hailar: Inner Mongolia People's Publ., 2018. 520 p. (In Chin.)

Novichkov V. S. The nature of ethnic policy in the PRC during the period of destruction (19561978). Tomsk State University Journal of History. 2017. No. 45. Pp. 48-54. (In Russ.)

Ochirov Ts. S. National minorities of the Hulunbuir Region during the 'Cultural Revolution' in the PRC: foreign historiography of the problem. Humanitarian Vector. 2019. Vol. 14. No. 3. Pp. 64-70. (In Russ.)

Ochirov Ts. S. The initial stage of the Cultural Revolution in the Inner Mongolia Autonomous Region of China (1966-1969). The Authority (Vlast'). 2020. Vol. 28. No. 1. Pp. 251-256. (In Russ.)

Ochirov Ts. S. To the study of the period of 'Cultural Revolution' in Khulun-Buir Aymak of the Inner Mongolia. In: Shalak A. V. et al. (eds.) Irkutsk Yearbook of History and Economics 2019. Irkutsk: Baikal State University, 2019. Pp. 375-380. (In Russ.) DOI 10.17150/978-57253-3001-4.50
Shirendyb B., Sladkovsky M. I. (eds.) People's Republic of China: Inner Mongolia Autonomous Region. Moscow: Nauka, 1980. 157 p. (In Russ.)

Sneath D. The impact of the Cultural Revolution in China on the Mongolians of Inner Mongolia. Modern Asian Studies. 1994. Vol. 28. No. 2. Pp. 409-430. (In Eng.)

Tsybenov B. D., Ochirov Ts. S. National minorities if the Khulun-Buir Region during the Cultural Revolution in the PRC: the Russian historiography of the problem. Bulletin of the Buryat Scientific Center of the Siberian Branch of the Russian Academy of Sciences. 2019. No. 1 (33). Pp. 108-115. (In Russ.) DOI 10.31554/2222-9175-2019-33-108-115

Tsybenov B. D., Ochirov Ts. S. Eyewitness accounts: memoirs and oral history of the 'Cultural Revolution' in Hulun-Buir. Bulletin of the Buryat Scientific Center of the Siberian Branch of the Russian Academy of Sciences. 2020. No. 1 (37). Pp. 68-76. (In Russ.) DOI 10.31554/2222-9175-2020-37-68-76

Tsybenov B. D. Socio-political development of the Morin-Dawa Autonomous Region in 19581984. The Authority (Vlast'). 2018. No. 7. Pp. 205-211. (In Russ.)

Tümen, Ju Dung Li. Kang Sheng and (His) False Accusations against the Inner Mongolia People's Liberation Party. Beijing: People's Publ. House, 1996. 594 p. (In Mong.)

Wu Shougui. Ewenki Society. Beijing: Nationalities Press, 2012. 548 p. (In Chin.)

$\mathrm{Xu}$ Zhanjiang. Buryats of China. Hailar: Inner Mongolia People's Publ., 2009. 356 p. (In Chin.)

Yang Haiying. Ulanhu a Nationalist Persecuted by the Chinese Communists. Nagoya: Association for Afro-Eurasian Inner Dry Land Civilization Studies, 2013. 102 p. (In Eng.)

Zhamsran L., Erdenebayar Y, Altantsetseg N. Mongols of China. Ulaanbaatar: Sükhbaatar, 1996. 182 p. (In Mong.)

Zhang Fuxiang (ed.) Hulunbuir Aimag of the Inner Mongolia Autonomous Region (China): Materials of the Local CCP Organization, September 1945 - December 1987. Hailar: Inner Mongolia People's Publ., 1989. 777 p. (In Chin.) 